\title{
UPAYA KERJA DALAM RANGKA MENINGKATKAN KINERJA PEGAWAI SEKRETARIAT BADAN DIKLAT PERHUBUNGAN DI JAKARTA
}

\author{
Syafek Jamhari*
}

\begin{abstract}
The main purposes of this research is to identify and acquire the necessary information regarding the work effort in improving employee's job performance. The research was conducted at Secretariat of Education and Training Agency on Ministry of Transportation in Jakarta, during October 2008 to January 2009. The method is survey with questionnaire as tool for data collecting. This research included 40 employees as unit analysis. Data is analyzed using descriptive approach. The results indicate the employees of Secretariat of Education and Training Agency on Ministry of Transportation in Jakarta have both high work effort and job performance. Based on those findings it could be concluded that high work effort has effected employees' job performance at Secretariat of Education and Training Agency on Ministry of Transportation in Jakarta. Therefore, the employees job performance should be kept by giving the rewards. It should be put into account in maintaining employees at Secretariat of Education and Training Agency on Ministry of Transportation in Jakarta.
\end{abstract}

Keywords: Work effort, job performance.

\section{PENDAHULUAN}

Berbagai masalah masih terdapat pada Pegawai Negeri Sipil (PNS) di Indonesia. Tampak jelas sekali kinerja PNS tidak produktif, bekerja secara lamban dan berbelitbelit, kurang efektif dan efisien, serta tidak mempunyai pekerjaan jelas. Kondisi ini juga dihadapi oleh PNS Sekretariat Badan Pendidikan dan Pelatihan Perhubungan di Jakarta. Permasalahan yang dihadapi terutama masalah integritas pegawai sebagai masalah yang kompleks. Kenyataan di lapangan menunjukkan bahwa ada masalah yang tidak boleh diabaikan begitu saja, termasuk: beban kerja yang diberikan kepada pegawai yang tidak merata dan dasar penempatan pegawai yang belum transparan. Pertama, beban kerja yang tidak merata menjadikan para pegawai terpecah menjadi dua. Di satu sisi, terdapat beberapa pegawai dengan beban pekerjaan yang menumpuk, di sisi lain, ada pegawai yang kurang mendapat cukup pekerjaan. Kedua, dasar penempatan pegawai belum transparan menjadikan beberapa pegawai kerap merasa kurang puas dengan kebijakan yang ada. Kondisi ini ternyata kurang mendukung upaya kerja dan kinerja pegawai. Kepercayaan pegawai yang kurang terhadap institusinya menimbulkan persepsi yang kurang baik terhadap atasannya. Moril kerja yang kurang baik ditunjukkan dengan upaya kerja yang tidak optimal. Pegawai tidak memanfaatkan segenap daya dan upaya kerja yang dimilikinya untuk bekerja dengan baik, padahal sebagaimana diatur dalam Peraturan Menteri Perhubungan Nomor: KM 43 Tahun 2005 tentang 0rganisasi dan Tata Kerja Departemen Perhubungan Pasal 761 menyatakan bahwa "Sekretaris Badan Pendidikan dan Pelatihan Perhubungan mempunyai tugas melaksanakan pembinaan dan pelayanan teknis dan administratif kepada seluruh satuan organisasi di lingkungan Badan Pendidikan dan Pelatihan Perhubungan". Hal inilah yang menarik untuk dikaji lebih lanjut dalam kaitannyc

\footnotetext{
* Kepala Bidang Perencanaan Pusat Pendidikan dan Pelatihan Aparatur Perhubungan di Sekretariat Badan Pendidikan dan Pelatihan Departemen Perhubungan.
} 
dengan upaya kerja dalam rangka meningkatkan kinerja pegawai Sekretariat Badan Pendidikan dan Pelatihan Perhubungan di Jakarta.

Tinjauan terhadap literatur-literatur terkait dengan permasalahan yang diteliti, dibagi menjadi dua kelompok, yaitu : upaya kerja dan kinerja.

\section{Upaya Kerja.}

Dalam memahami upaya kerja, maka para peneliti berusaha untuk membuat model berbagai dimensi yang mendasari upaya kerja tertentu. Diantaranya teori tindakan berasalan seperti terlihat pada gambar berikut:

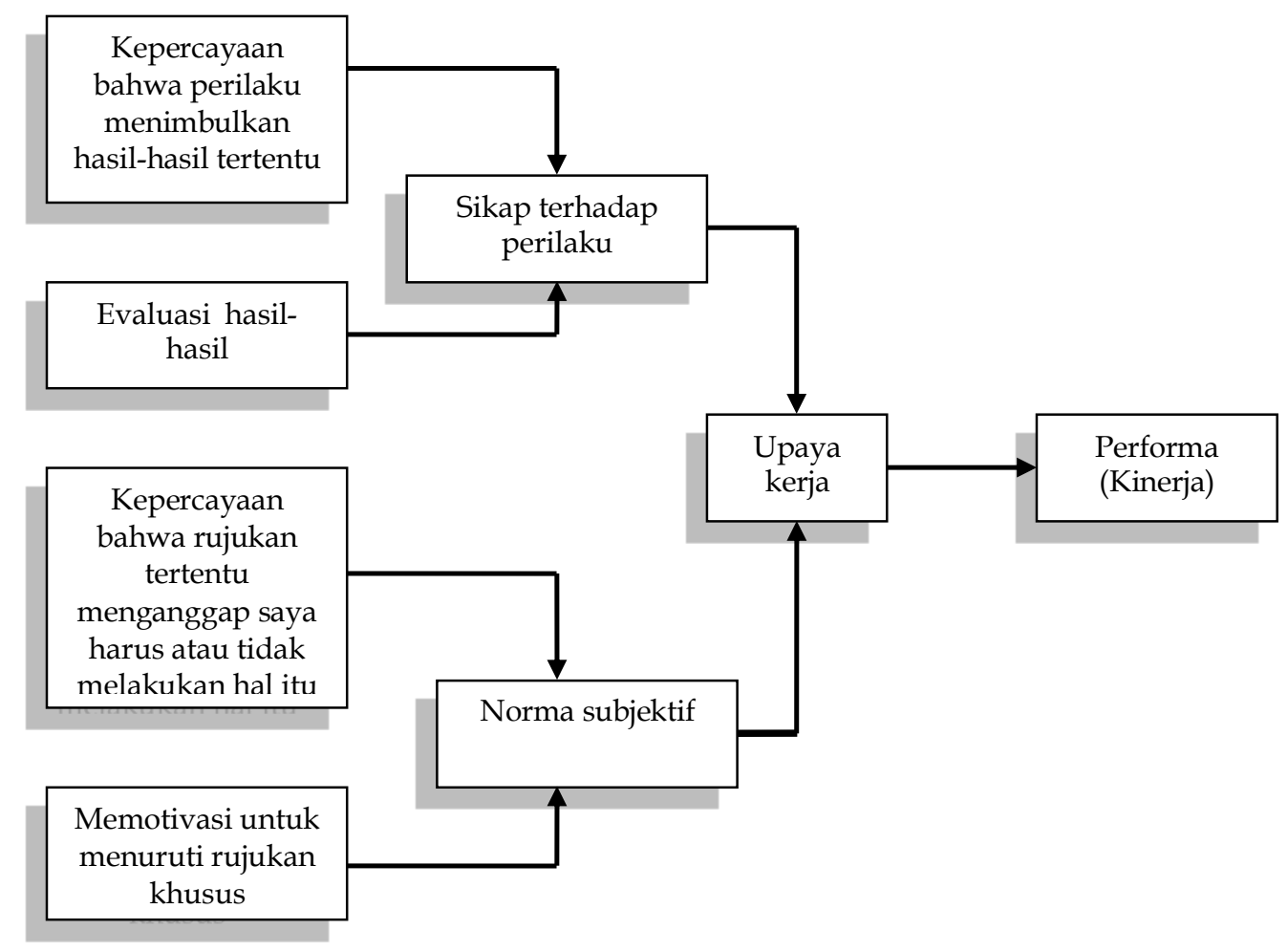

Gambar 1. Tindakan Beralasan

Sumber: Leon G. Schiffman, \& Leslie Lazar Kanuk, Perilaku Konsumen terjemahan Zoelkifli Kasip (Indeks: Jakarta, 2000), p. 229

Gambar di atas menunjukkan bahwa upaya kerja pada hakikatnya ditentukan oleh dua variabel utama yaitu sikap terhadap perilaku dan norma subjektif. Kedua hal inilah yang membentuk upaya kerja seseorang. Sedangkan menurut Vroom, seseorang akan memberikan upaya kerjanya, jika ia telah dapat menggambarkan hasil dari upaya kerjanya tersebut. Penjelasan Vroom ini dapat digambarkan dalam model diagram pohon berikut ini. 
Perceived probability of successful performance, given effort
Perceived probability of receiving an outcome, given successful performance
Perceived probability of a first level outcome leading to a second level outcome

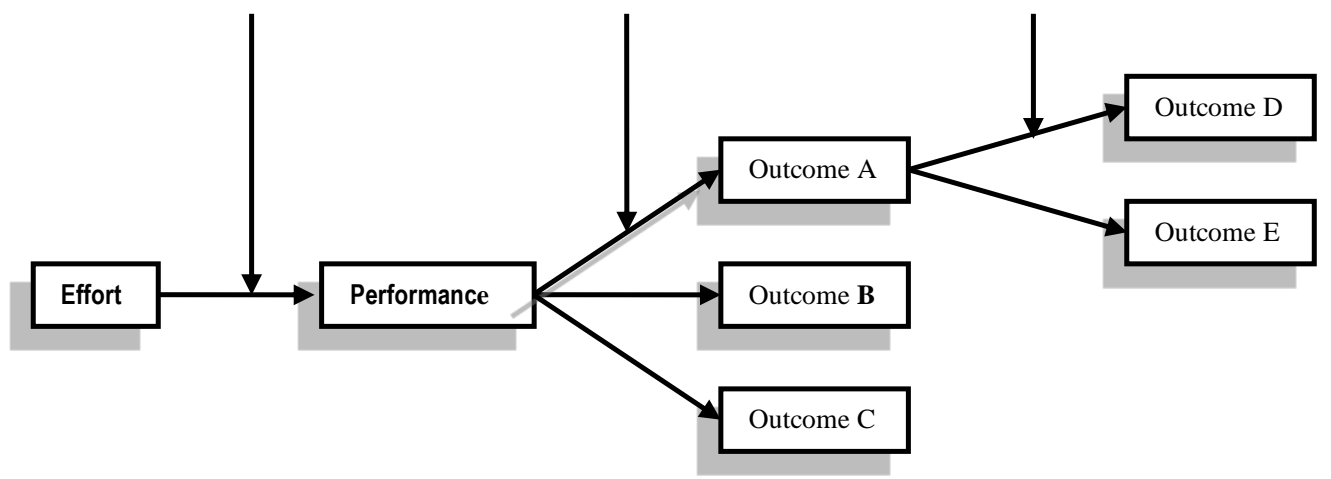

Gambar 2. Expectancy Theory

Sumber: Andrew Kakabadse, John Bank, \& Susan Vinnicombe, Working in Organizations (New York: Penguin, 2005), p. 65.

Menurut Bateman and Snell (2007:434) upaya kerja seseorang terhadap hubungan kinerja merupakan suatu ekspektansi, maksudnya upaya orang-orang akan memungkinkan mencapai tujuan kinerjanya (the effort to performance link, expectancy, is people's perceived likelihood that their efforts will enable them to attain their performance goals). Upaya kerja dapat dilihat dari perilaku seseorang yang menunjukkan adanya suatu usaha untuk melakukan sesuatu. Hal ini seperti yang diungkapkan oleh Morrow yang dikutip oleh Andrew Kakabadse (2005:71) bahwa upaya kerja meliputi: (1) semangat kerja akan meningkatkan kerja keras seseorang; (2) komitmen seseorang pada karirnya merupakan dorongan yang kuat untuk bekerja; (3) komitmen organisasi merupakan gairah seseorang untuk tetap bekerja pada organisasi itu; (4) nilai-nilai organisasi, visi, identitas organisasi, merupakan organisasi komitmen di tingkat afeksi yang akan mendorong karyawan tetap bekerja; dan (5) keterlibatan kerja merupakan tingkatan mengidentifikasi pekerjaan yang akan mendorong seseorang bekerja dengan giat. Setidaknya ada lima kriteria atau indikator upaya kerja seseorang, yaitu: semangat kerja, komitmen terhadap karir, gairah kerja, dorongan kerja, dan keterlibatan dalam bekerja. Dari uraian di atas, dapat disimpulkan bahwa upaya kerja adalah perilaku seseorang dalam menjalankan tugas dan tanggungjawabnya sesuai dengan perannya dalam mencapai tujuan yang telah ditentukan, yang ditunjukkan dengan: semangat kerja; kesetiaan pada karir; kesetiaan pada organisasi; keberpihakan terhadap organisasi; dan keterlibatan kerja.

\section{Kinerja}

Kinerja merupakan besarnya kontribusi individu dalam mencapai tujuan dan sasaran organisasi. Sebagaimana diungkapkan oleh Evans (2005) bahwa performance simply means the extent to which an individual contributes to achieving the goals and objectives of an organization. Kinerja merupakan seberapa besar kontribusi individu dalam mencapai sasaran dan tujuan organisasi. Sedangkan Rivai dan Basri (2005) mengatakan bahwa kinerja adalah hasil atau tingkat keberhasilan seseorang secara keseluruhan 
selama periode tertentu dalam melaksanakan tugas dibandingkan dengan berbagai kemungkinan, seperti standar hasil kerja, target atau sasaran, serta kriteria yang telah ditentukan terlebih dahulu dan disepakati bersama-sama.

Menurut Schecner (1999:78), kinerja adalah tingkat efisiensi dan produktivitas kerja yang dapat dipantau dari catatan yang ada pada lembaga atau organisasi tempat seseorang bekerja. Hal ini dimaksudkan bahwa kinerja itu selalu berhubungan langsung dengan efisiensi, efektivitas, dan produktivitas kerja seorang pegawai dalam melaksanakan pekerjaannya guna mencapai tujuan organisasi. Stolovich dan Keeps (1992:14) menyatakan bahwa kinerja adalah seperangkat hasil yang dicapai dan merujuk pada tindakan pencapaian serta pelaksanaan sesuatu pekerjaan yang diminta. Batasan ini menunjukkan bahwa kinerja mengandung indikator: (1) penyelesaian tugas; (2) pencapaian tujuan; (3) konsistensi dalam bertindak; (4) kedisiplinan; dan (5) pemberian dukungan. Sementara itu, Campling et al., menyatakan bahwa upaya kerja dapat digunakan untuk meningkatkan kinerja sebagaimana dijelaskan pada gambar berikut.

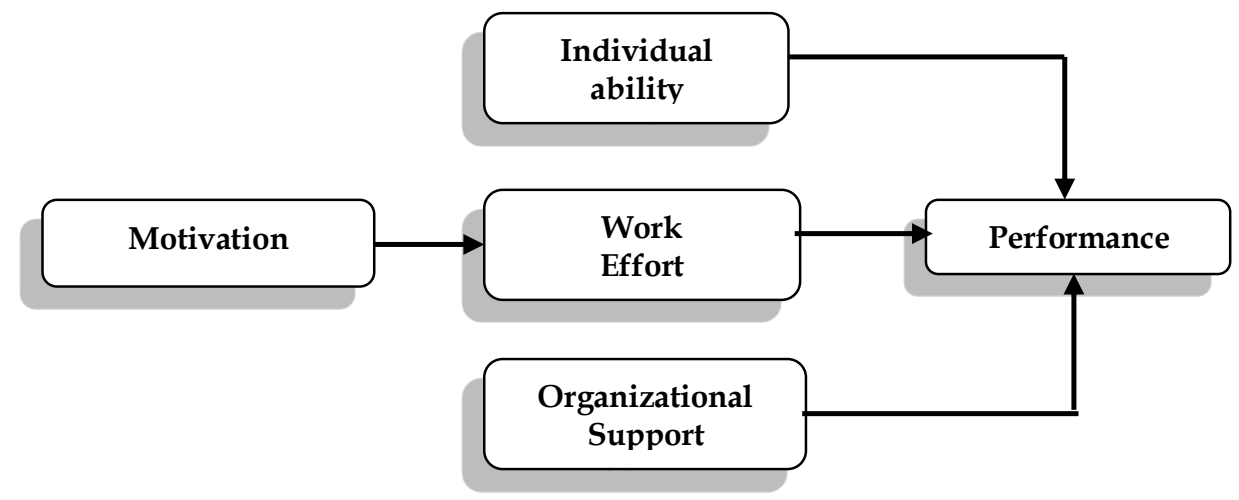

\section{Gambar 3 Pengaruh Motivasi, Kemampuan Individu, Upaya Kerja, dan Dukungan Organisasi terhadap Kinerja}

Sumber: John Campling et al., Management (Sydney: John Wiley \& Sons Australia, Ltd, 2006), p. 401.

Gambar di atas menunjukkan bahwa upaya kerja merupakan bentuk konkrit perilaku seseorang setelah mendapatkan motivasi untuk bekerja. Upaya kerja seseorang akan optimal bila didukung oleh kemampuan individu dan dukungan organisasi. Pada akhirnya akan menghasilkan kinerja yang optimal juga.

\section{METODE}

Penelitian ini menggunakan metode deskriptif. Adapun pendekatan yang digunakan adalah pendekatan kualitatif. Dalam penelitian ini, pengumpulan data dilakukan dengan teknik wawancara yang didukung dengan angket. Unit analisis yang

digunakan dalam penelitian ini adalah pegawai Sekretariat Badan Pendidikan dan Pelatihan Perhubungan di Jakarta yang mewakili tiap-tiap bagian, di Sekretariat Badan Pendidikan dan Pelatihan Perhubungan terdapat 4 Bagian. Dalam rangka penyebaran angket, diambil sampel sebanyak 40 orang pegawai/staf Sekretariat Badan Pendidikan dan Pelatihan Perhubungan yang diambil secara acak sederhana (simple random sampling). Proses analisis data yang dilakukan untuk mendapatkan kesimpulan dengan menggunakan statistik deskriptif. 


\title{
HASIL DAN PEMBAHASAN
}

Berdasarkan data yang diperoleh dalam penelitian dapat dikemukakan bahwa Upaya Kerja Pegawai pada Badan Diklat Perhubungan Jakarta tergolong tinggi. Upaya kerja pegawai dapat diketahui dari berbagai indikator, yaitu: 1) semangat kerja; 2) kesetiaan pada karir; 3) kesetiaan pada organisasi; 4) keberpihakan terhadap organisasi; dan 5) keterlibatan kerja dengan skor sebagai berikut.

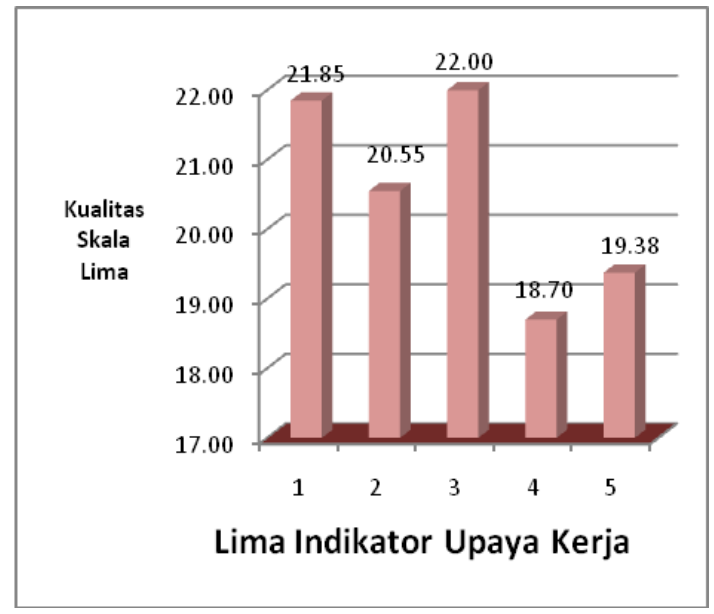

\section{Gambar 4. Histogram Skor Indikator Variabel Upaya Kerja Pegawai}

\author{
Keterangan: \\ Lima Indikator Upaya Kerja Pegawai \\ 1. Semangat kerja \\ 2. Kesetiaan pada karir \\ 3. Kesetiaan pada organisasi \\ 4. Keberpihakan terhadap organisasi \\ 5. Keterlibatan kerja
}

Gambar di atas menunjukkan bahwa indikator kesetiaan pada organisasi merupakan skor tertinggi $(22,00 \%)$ dalam variabel Upaya Kerja Pegawai. Seperti yang diungkapkan oleh Morrow yang dikutip oleh Kakabadse, Bank, dan Vinnicombe (2005, 17) upaya kerja nampak pada: semangat kerja akan meningkatkan kerja keras seseorang, kesetiaan seseorang pada karirnya merupakan dorongan yang kuat untuk bekerja, kesetiaan pada organisasi merupakan gairah seseorang untuk tetap bekerja pada

organisasi itu. Nilai-nilai, visi, identitas organisasi, merupakan kesetiaan pada organisasi di tingkat afeksi yang akan mendorong pegawai tetap bekerja, dan keterlibatan kerja merupakan tingkatan mengidentifikasi pekerjaan yang akan mendorong seseorang bekerja dengan giat.

Berdasarkan data yang diperoleh dalam penelitian dapat dikemukakan bahwa Kinerja Pegawai Sekretariat Badan Diklat Perhubungan Jakarta tergolong tinggi. Kinerja pegawai dapat diketahui dari berbagai indikator, yaitu: 1) penyelesaian tugas; 2) pencapaian tujuan; 3) konsistensi dalam bertindak; 4) kedisiplinan; dan 5) Pemberian dukungan dengan skor sebagai berikut.

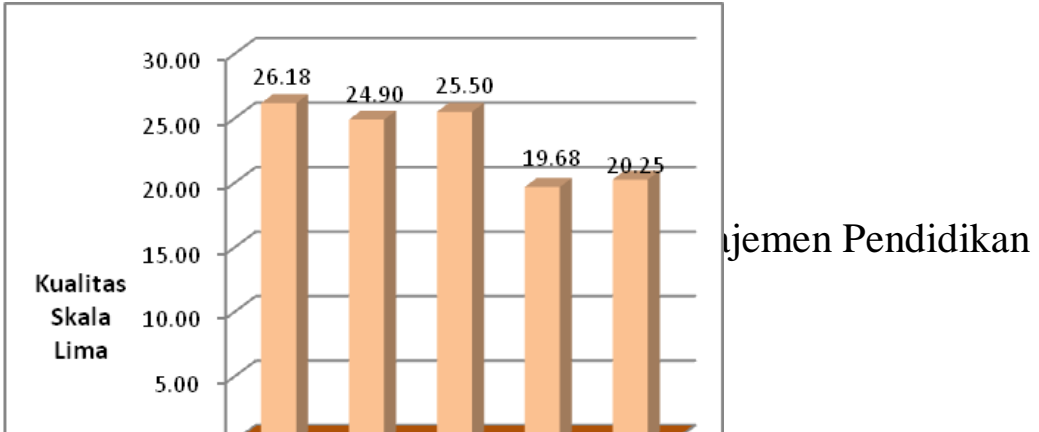




\title{
Gambar 5. Histogram Skor Indikator Variabel Kinerja Pegawai
}

\author{
Keterangan: \\ Lima Indikator Kinerja Pegawai \\ 1. Penyelesaian tugas \\ 2. Pencapaian tujuan \\ 3. Konsistensi dalam bertindak \\ 4. Kedisiplinan \\ 5. Pemberian dukungan
}

Gambar di atas menunjukkan bahwa indikator penyelesaian tugas merupakan skor tertinggi $(26,18 \%)$ dalam dalam variabel Kinerja Pegawai. Hal ini sesuai dengan teori yang dikemukakan Donelly, Gibson, dan Ivancevich (1994:15) bahwa kinerja merujuk pada tingkat keberhasilan dalam melaksanakan tugas serta kemampuan untuk mencapai tujuan yang telah ditetapkan. Kinerja dinyatakan baik dan sukses jika tujuan yang diinginkan dapat tercapai dengan baik.

Data-data penelitian menunjukkan bahwa pegawai Sekretariat Badan Diklat Perhubungan di Jakarta memiliki upaya kerja yang tinggi. Hal ini ditunjukkan oleh sebagian besar responden memiliki skor indikator Upaya Kerja yang mendekati skor maksimum teoretiknya. Sebagian besar responden menunjukkan semangat kerja yang tinggi. Pegawai terdiri dari individu-individu yang setia pada karir dan organisasi.

Pegawai merupakan individu-individu yang berpihak pada organisasi, dan senantiasa berupaya aktif dalam melibatkan diri dalam bekerja.

Demikian halnya, Kinerja pegawai, Sebagian besar responden memiliki skor Kinerja yang mendekati skor maksimum teoretiknya. Sebagian besar responden menunjukkan penyelesaian tugas, pencapaian tujuan, konsistensi dalam bertindak, kedisiplinan, dan pemberian dukungan.

Tabel 1. Rangkuman Statistik Deskriptif Variabel Upaya Kerja dan Kinerja Pegawai 


\begin{tabular}{|l|r|r|}
\hline \multicolumn{1}{|c|}{ Statistics } & \multicolumn{1}{c|}{$\boldsymbol{X}$} \\
\hline & & \multicolumn{1}{c|}{$\boldsymbol{Y}$} \\
\hline Mean & 102.48 & 116.51 \\
\hline Standard Error & 1.315562666 & 1.535138639 \\
\hline Median & 103 & 117 \\
\hline Mode & 108 & 117 \\
\hline Standard Deviation & 8.320348859 & 9.709069247 \\
\hline Sample Variance & 69.22820513 & 94.26602564 \\
\hline Range & 41 & 36 \\
\hline Minimum & 80 & 95 \\
\hline Maximum & 121 & 131 \\
\hline Sum & 4098 & 4645 \\
\hline Count (N) & 40 & 40 \\
\hline
\end{tabular}

Upaya kerja yang ditunjukkan pegawai sekretariat badan diklat perhubungan Jakarta mendukung Kinerjanya. Dalam Tabel 1 dapat dilihat bahwa nilai skor rata-rata Upaya Kerja yang tinggi, yaitu 102,48 diikuti oleh nilai skor rata-rata Kinerja pegawai yang juga tinggi, yaitu 116,51. Dalam Gambar 4 semakin jelas dapat dilihat bahwa Upaya Kerja pegawai sangat mendukung Kinerjanya. Dalam Gambar 4 juga dapat dilihat bahwa variasi frekuensi atau jumlah pegawai pada kedua variabel hampir sama. Artinya, pada interval Upaya Kerja dengan frekuensi yang rendah diikuti juga oleh rendahnya frekuensi pada interval Kinerja pegawai. Selanjutnya, ketika frekuensi pada interval Upaya Kerja mengalami kenaikan maka frekuensi pada interval Kinerja juga meningkat. Variasi dengan arah yang sama antara Upaya Kerja dan Kinerja pegawai menunjukkan bahwa Upaya Kerja sangat mendukung Kinerja pegawai.
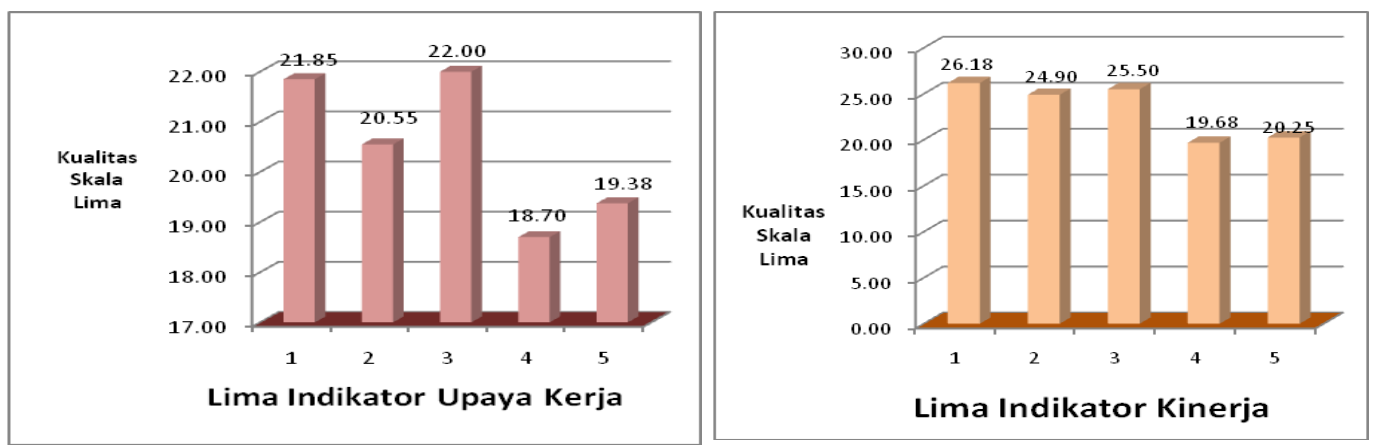


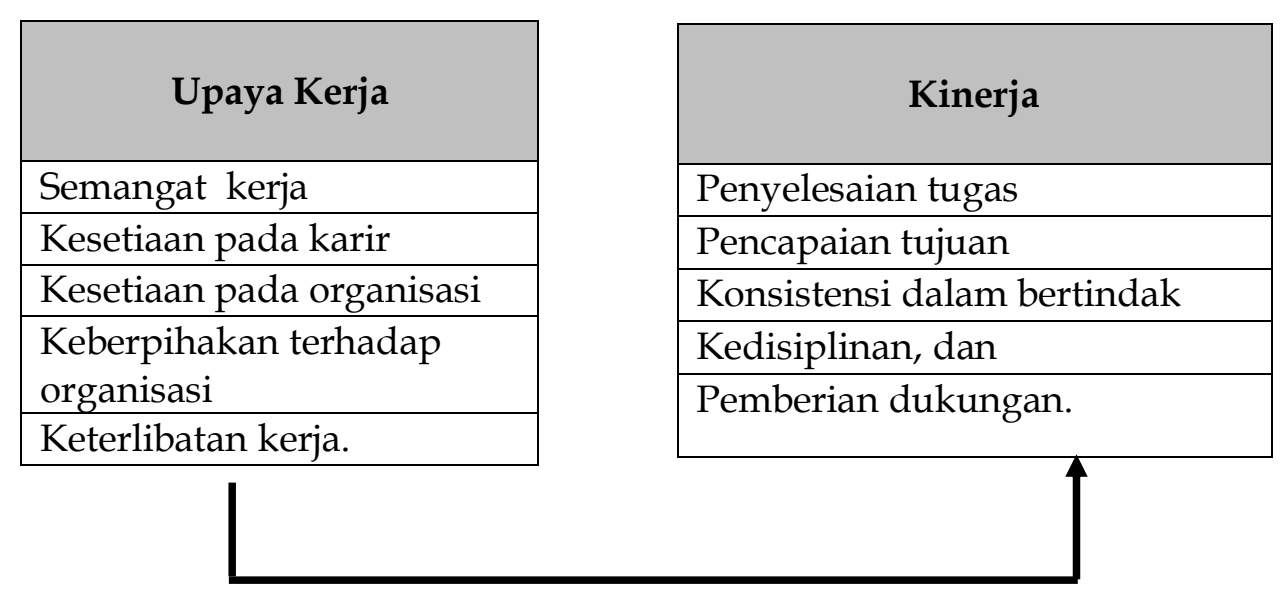

\section{Gambar 6. Diagram Batang Skor Indikator Upaya Kerja dan Kinerja Pegawai}

Pada kenyataan, sebagaimana dapat dilihat pada Gambar 6, hasil-hasil yang didapatkan dalam penelitian sesuai dengan yang terjadi atau ditemui dalam pegawai Sekretariat Badan Diklat Perhubungan di Jakarta. Gambar 6 tersebut menyajikan variasi skor variabel Upaya Kerja dan Kinerja pegawai. Dalam gambar tersebut dapat dilihat bahwa fluktuasi variasi skor kedua variabel mempunyai pola yang hampir sama. Artinya, pada saat Upaya Kerja pegawai meningkat maka Kinerjanya juga meningkat. Sebaliknya, Kinerja menurun pada saat Upaya Kerjanya menurun. Para pegawai dengan Upaya Kerja yang tinggi ternyata mempunyai Kinerja yang tinggi pula. Sebaliknya, para pegawai dengan Kinerja yang rendah ternyata disebabkan oleh rendahnya Upaya Kerja mereka. Hal ini terjadi baik karena semangat kerja pegawai yang rendah atau rendahnya keterlibatan para pegawai yang menyebabkan pencapaian tujuan yang belum optimal. Upaya kerja seorang pada akhirnya akan menggerakkan seluruh organisasi dalam mencapai sasaran-sasaran yang telah ditetapkan.

Upaya kerja merupakan kontribusi seseorang terhadap organisasinya. Kontribusi yang besar dari seorang tentunya akan mempengaruhi prestasi dan kinerjanya, begitu juga sebaliknya. Sebagaimana teori yang disampaikan Wagner dan Hollenbeck (1992: 224) melihat bahwa kombinasi dari faktor-faktor upaya kerja, kemampuan, dan ketepatan persepsi peran berdampak pada perilakunya pada akhirnya menghasilkan kinerja. Hal ini

ditunjukkan oleh pegawai Sekretariat Badan Diklat Perhubungan di Jakarta. Demikian

juga, teori yang disampaikan oleh Morrow yang dikutip oleh Andrew Kakabadse (2005:71) yang terjadi pada masing-masing indikator. 
Pertama, semangat kerja akan meningkatkan kerja keras seseorang. Hal ini ditunjukkan dengan variasi semangat kerja pegawai diikuti oleh variasi dalam menyelesaikan tugas. Kedua, komitmen pegawai pada karirnya merupakan dorongan yang kuat untuk bekerja. Hal ini ditunjukkan dengan variasi komitmen pegawai diikuti oleh variasi dalam mencapai tujuan. Ketiga, komitmen organisasi merupakan gairah seseorang untuk tetap bekerja pada organisasi itu. Hal ini ditunjukkan dengan variasi kesetiaan pegawai pada organisasi diikuti oleh variasi konsistensi pegawai dalam bertindak. Keempat, nilai-nilai organisasi, visi, identitas organisasi, merupakan organisasi komitmen di tingkat afeksi yang akan mendorong karyawan tetap bekerja. Hal ini ditunjukkan dengan variasi keberpihakan pegawai pada organisasi diikuti variasi kedisiplinan pegawai. Kelima, keterlibatan kerja merupakan tingkatan mengidentifikasi pekerjaan yang akan mendorong seseorang bekerja dengan giat. Hal ini ditunjukkan dengan variasi keterlibatan pegawai diikuti oleh variasi pegawai dalam memberi dukungan.

\section{PENUTUP}

Kesimpulan. Hasil analisis tentang upaya kerja dalam meningkatkan kinerja pegawai Sekretariat Badan Diklat Perhubungan di Jakarta ternyata: (1) Sebagian besar pegawai Sekretariat Badan Diklat Perhubungan di Jakarta menunjukkan upaya kerja yang sedang dan tinggi, serta tidak ada yang menunjukkan upaya kerja yang rendah. Hal ini ditunjukkan dengan semangat kerja; kesetiaan pada karir; kesetiaan pada organisasi; keberpihakan terhadap organisasi; dan keterlibatan kerja; (2) Sebagian besar pegawai Sekretariat Badan Diklat Perhubungan di Jakarta memiliki kinerja yang tinggi dan tidak ada yang memiliki Kinerja yang rendah. Hal ini ditunjukkan dengan penyelesaian tugas, pencapaian tujuan, konsistensi dalam bertindak, kedisiplinan, dan pemberian dukungan; (3) Variasi dalam upaya kerja diikuti oleh variasi Kinerja. Pegawai Sekretariat Badan Diklat Perhubungan di Jakarta yang memiliki upaya kerja yang tinggi menunjukkan kinerja yang tinggi pula, sebaliknya pegawai dengan upaya kerja yang rendah menunjukkan kinerja yang rendah. Berdasarkan hasil analisis data penelitian dengan teori-teori yang mendukung terbukti bahwa kinerja pegawai Sekretariat Badan Diklat Perhubungan di Jakarta dapat ditingkatkan melalui upaya kerjanya.

Saran. Berdasarkan kesimpulan di atas, maka selanjutnya penulis menyampaikan beberapa saran sebagai berikut: Pertama, Sekretaris Badan Diklat Perhubungan di Jakarta hendaklah dapat mempertahankan upaya kerja pegawai dalam rangka meningkatkan kinerjanya yang dapat dilakukan dengan meningkatkan semangat kerja, kesetiaan pada karir, kesetiaan pada organisasi, keberpihakan pada organisasi, dan keterlibatan pegawai dalam kerja. Kedua, Para Kepala Bagian dan Subbagian Badan Diklat Perhubungan di Jakarta seharusnya lebih memperhatikan upaya kerja pegawai sehingga kinerja pegawai lebih ditingkatkan. Hal ini dapat dilakukan dengan senantiasa mendorong pegawai untuk lebih memahami arti penting upaya kerja dan kinerjanya. Terakhir, Para pegawai Sekretariat Badan Diklat Perhubungan di Jakarta

seharusnya dapat meningkatkan upaya kerja dalam rangka meningkatkan kinerja. Hal ini perlu dilakukan dengan peningkatan pemahaman dan tanggung jawab terhadap tugas yang semakin kompleks di era informasi. 


\section{DAFTAR RUJUKAN}

Bateman, Thomas S. and Scott A. Snell, Management, Leading $\mathcal{E}$ Collaborating in a Competitive World. New York: McGraw-Hill, 2007.

Campling, John et al. Management: $2^{\text {nd }}$ Asia-Pacific Edition. Sydney: John Wiley \& Sons Australia, Ltd, 2006.

Evans, James R. Total Quality: Management, Organization, and Strategy. Canada: South western-Thomson Corporation, 2005.

Kakabadse, Andrew John Bank, \& Susan Vinnicombe. Working in Organizations. New York: Penguin, 2005.

Rivai, Veithzal dan Dato, Achmad Fawzi Mohd. Basri, Performance Apraisal. Jakarta: PT. Rajagrafindo Persada, 2005.

Schecner, Richard, Performance Theory. New York: Routledge, 1990.

Schiffman, Leon G. \& Leslie Lazar Kanuk, Perilaku Konsumen terjemahan Zoelkifli Kasip Indeks: Jakarta, 2000.

Stolovich, Harold D. and Erica J. Keeps, Handbook of Human Performance Technology A Comprehensive Guide for Analysis and Solving Performance Problem in Organizations. San Fransisco: Jorney-Bass Publisher, 1992. 